\title{
Pain Symptoms in Patients with Coronavirus Disease (COVID-19): A Literature Review
}

This article was published in the following Dove Press journal:

Journal of Pain Research

\author{
Lin-Man Weng $\mathbb{D}^{1, *}$ \\ Xuan $\mathrm{Su}^{\mathrm{I}} *$ * \\ Xue-Qiang Wang $\mathbb{D}^{1,2}$ \\ 'Department of Sport Rehabilitation, \\ Shanghai University of Sport, Shanghai, \\ People's Republic of China; ${ }^{2}$ Department \\ of Rehabilitation Medicine, Shanghai \\ Shangti Orthopaedic Hospital, Shanghai, \\ People's Republic of China
}

*These authors contributed equally to this work
Correspondence: Xue-Qiang Wang Department of Sport Rehabilitation, Shanghai University of Sport, Shanghai,

People's Republic of China

$\mathrm{Tel} / \mathrm{Fax}+8602165503470$

Email Qiang897@I63.com
Purpose: On 11 March, 2020, the coronavirus disease (COVID-19) outbreak was declared as a global pandemic by the World Health Organization. It brought substantial physical and psychological burden on individuals and financial loss across countries. Patients with COVID-19 may exhibit various symptoms, such as fever, cough, dyspnea, muscle pain, sore throat, headache, chest pain, and abdominal pain, at 2-14 days after exposure to the novel coronavirus (severe acute respiratory syndrome [SARS]-CoV-2). Pain symptoms present important challenge to clinicians' diagnosis when treating COVID-19 patients with mild symptoms. Considering the increasing number of confirmed COVID-19 cases, the pain symptoms should be systematically summarized.

Results: The virus can invade different tissues of the body and cause different pain manifestations. SARS-CoV-2 primarily invades the respiratory system, and patients develop sore throat, fever, cough, and other pneumonia-associated symptoms. Moreover, it infects the nervous system (eg, headache, dizziness, and confusion), digestive system (eg, abdominal pain, diarrhea), and cardiovascular system (eg, chest pain, palmus, and cardiac injury). The incidence rate is $1.7-33.9 \%$ for headache, $0.7-47.1 \%$ for sore throat, $1.5-61.0 \%$ for myalgia/ arthralgia, $1.6-17.7 \%$ for chest pain, and $1.9-14.5 \%$ for abdominal pain. In comparison with chest and abdominal pain, COVID-19 patients are more likely to develop headache, sore throat, and myalgia/arthralgia.

Conclusion: Different pain reflects the damage of different body systems. Therefore, the summary of pain symptoms for COVID-19 patients can help doctors improve the accuracy and efficiency of diagnosis when treating COVID-19 patients with atypical or mild symptoms and adopt more targeted treatment methods.

Keywords: pain, COVID-19, SARS-CoV-2, symptom

\section{Introduction}

On 11 March 2020, the coronavirus disease (COVID-19) outbreak was declared as a global pandemic by the World Health Organization. ${ }^{1}$ The WHO reported that the total number of confirmed COVID-19 cases has increased sharply to $79,231,893$ (1,754,574 deaths, $2.21 \%$ fatality ratio) in 219 countries/territories/ areas as of December 29, 2020. ${ }^{2}$ The fatality ratio in France, Italy, and United Kingdom reached 2.48\% (62,197 deaths, 2,507,532 confirmed cases), $3.52 \%$ (71,620 deaths, 2,038,759 confirmed cases), and 3.12\% (70,405 deaths, 2,256,009 confirmed cases), respectively. ${ }^{2}$ The spread of COVID-19 is becoming unstoppable across the world, ${ }^{3,4}$ and the global pandemic brought substantial physical and psychological burden on individuals and financial loss across countries. $^{5-7}$ 
Patients with COVID-19 exhibit various symptoms, such as fever, cough, dyspnea, muscle pain, headache, sore throat, chest pain, and abdominal pain, at 2-14 days after exposure to the novel coronavirus (severe acute respiratory syndrome [SARS]-CoV-2). ${ }^{8-17}$ Huang et al ${ }^{10}$ first reported the clinical symptoms at the onset of illness in patients with COVID-19, in which fever was the most common symptom (98\%), followed by cough (76\%), dyspnea $(55 \%)$, muscle pain or fatigue (44\%), sputum production $(28 \%)$, headache $(8 \%)$, haemoptysis $(5 \%)$, and diarrhoea (3\%). Guan et $\mathrm{al}^{9}$ found that the common pain symptoms include myalgia or arthralgia (14.9\%), sore throat (13.9\%), and headache (13.6\%). Apart from respiratory symptoms, pain symptoms, such as headache, sore throat, myalgia or arthralgia, chest pain, and abdominal pain are common in patients with COVID-19. Similarly, patients with SARS also reported pain symptoms. ${ }^{18-21}$ such as myalgia (49.3-60.9\%), headache (35.4-55.8\%), sore throat (12.5-23.2\%), chest pain (10.4\%), and abdominal pain (3.5\%).

Due to the high incidence of pain, it can be used as a symptom identified in the course of COVID-19, reminding people with pain to be vigilant and help doctors diagnose as soon as possible. In addition, it also presents important challenge to clinicians' diagnosis when treating patients with COVID-19 having mild symptoms. Considering the increasing number of confirmed COVID19 cases, the pain symptoms of COVID-19 should be systematically summarized. At present, no reviews of pain symptoms for these patients with COVID-19 have been done. This review aimed to elaborate the pain symptoms of patients with COVID-19 based on published data.

\section{Headache}

Headache refers to the pain in the head or upper neck. ${ }^{22}$ Globally, the prevalence of general population is $47 \%$ and the lifetime prevalence is $66 \%{ }^{23}$ For individuals, this condition can cause suffering, reduced quality of life, and disability. ${ }^{24}$ Headache is also a very common clinical symptom, and the infection with the COVID-19 is not an exception. In a recent retrospective case study, in which Guan et al analyzed data from 1590 patients with COVID19 in China between 11 December 2019 and 31 January 2020, the incidence of headache was $15.4 \%$. Among the 1328 patients with valid data, 205 patients reported headaches. ${ }^{25}$ Up to April 12, 2020, based on the 11th epidemiological report issued by COVID-19 National Incident Room Surveillance Team, 6394 confirmed cases were reported in Australia, in which 36\% reported headache $(n=2010) .{ }^{26}$ Table 1 summarizes the five types of pain in different studies of COVID-19. The incidence rate of headache is $1.7-33.9 \%$ (Figure 1). ${ }^{16,27}$

The mechanism of COVID-19-induced headache remains unclear. We list some possible reasons. First, the levels of cytokines in the serum of patients with COVID19 were elevated, including tumor necrosis factor, interleukin 2, and granulocyte macrophage-colony stimulating factor. ${ }^{10,28,29}$ These cytokines released by immune cells in response to viral infections may cause headache. ${ }^{30,31}$ Second, when SARS-CoV-2 invades lung tissue, it may cause alveolar gas exchange disorders, leading to hypoxia in the brain, increasing the anaerobic metabolism of mitochondria in brain cell and accumulation of acid metabolites. It will cause obstruction of cerebral blood flow, swelling of brain cells, cerebrovascular dilatation and headache due to ischemia and congestion. ${ }^{32}$ Moreover, headache may result from the direct invasion of SARS$\mathrm{CoV}-2$ into the nervous system. Besides headache, some patients also presented neurological symptoms, such as dizziness, nausea, and vomiting. ${ }^{33,34}$ The results of autopsy on patients with COVID-19 revealed the congestion and edema of brain tissue, where some neurons degenerate. And some researchers detected SARS-CoV-2 in the cerebrospinal fluid of confirmed patients by genome sequencing. ${ }^{32}$ Neuronal pathway is an important way for neurotropic viruses to enter the central nervous system. Two experimental studies showed that SARS-CoV or Middle East respiratory syndrome coronavirus (MERS$\mathrm{COV}$ ) could enter some brain areas in transgenic mice via the olfactory nerves when administered intranasally. ${ }^{35,36}$ Considering the similar structure and pathogenesis of SARS-CoV-2, SARS-CoV and MERS$\mathrm{COV}^{37}$ this mechanism can also be applied to this novel coronavirus. The main routes of COVID-19 transmission among people are close contact and droplet contagion. The trigeminal nerve or the solitary tract is infected due to the contact of the eye conjunctiva or tongue taste buds with droplets containing SARS-CoV-2, the virus can infect the central nervous system (CNS) through retrograde traveling. As the respiratory droplets containing SARS-CoV-2 reach the nasal mucosa, the virus may directly infect olfactory sensory neurons and then enter the brain from olfactory nerve. ${ }^{38}$ In a transgenic mouse model of human angiotensin converting enzyme 2 (ACE2) infected by SARS-CoV, the olfactory nerve was the route for the virus to enter and infect the CNS; however, there were 


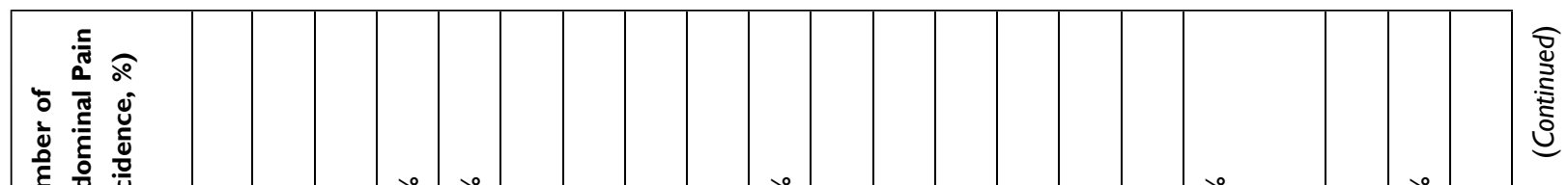

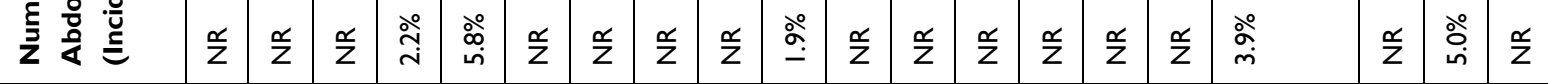

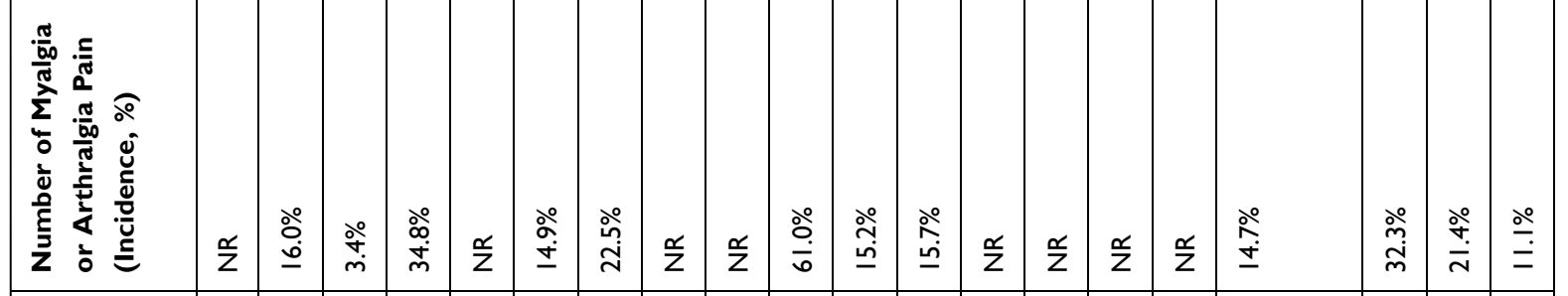

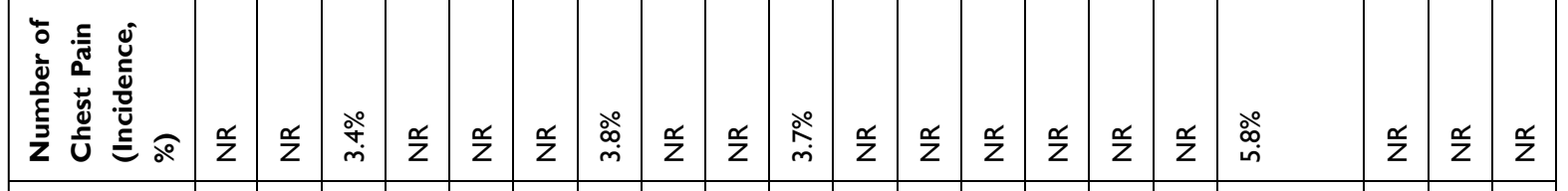

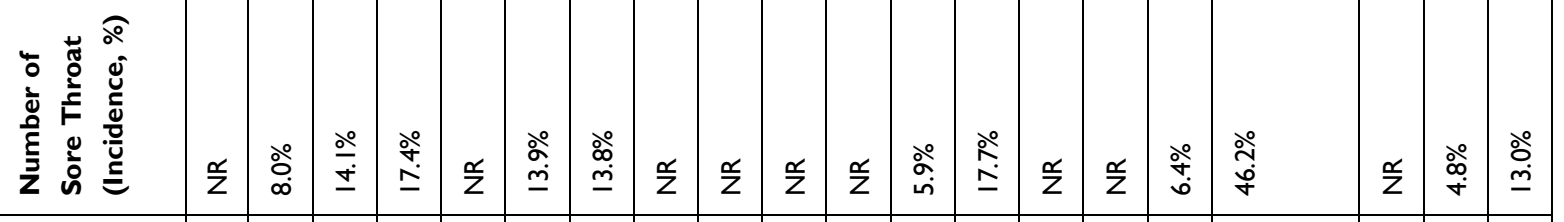

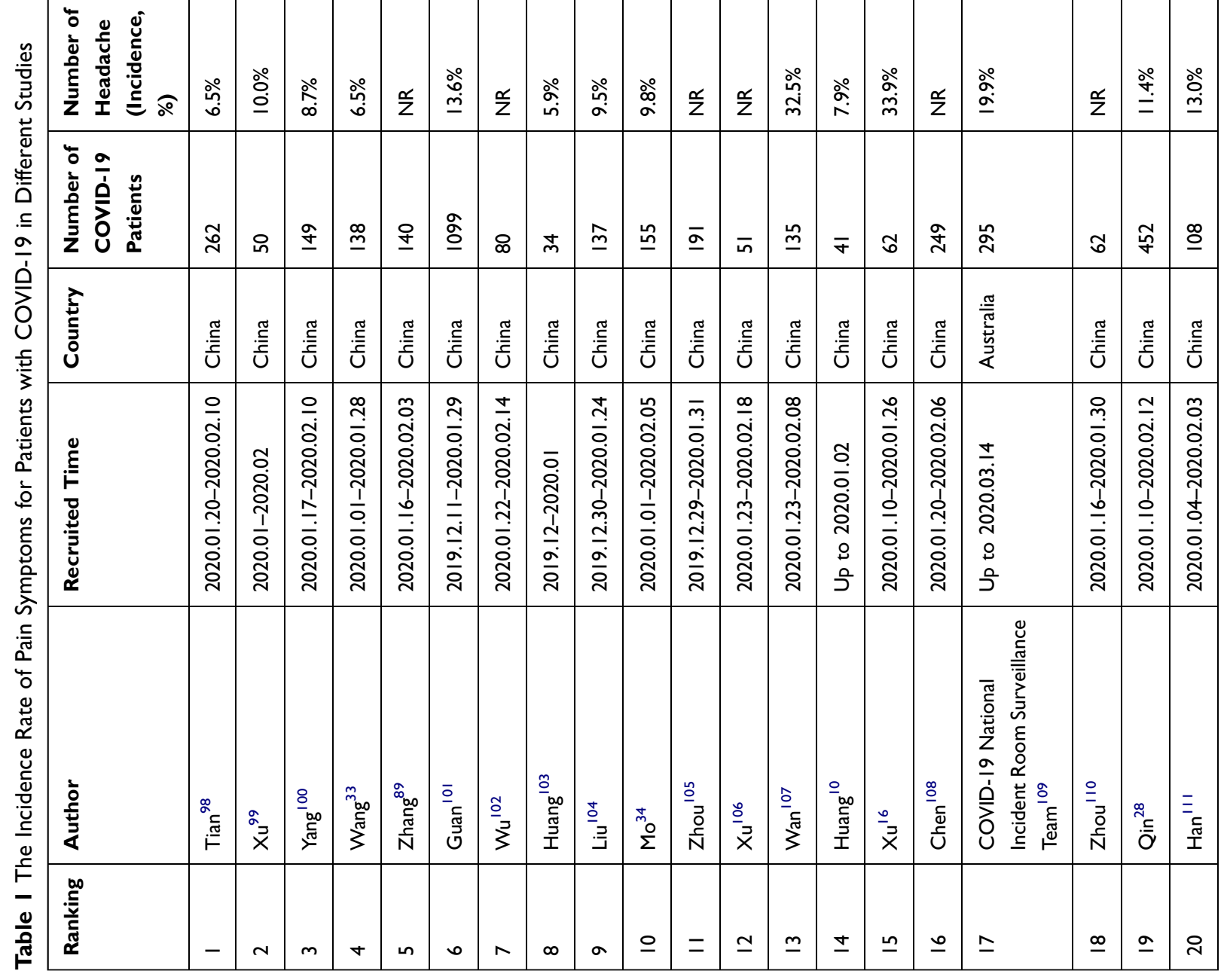




\begin{tabular}{|c|c|c|c|c|c|c|c|c|c|c|c|c|c|c|c|c|c|c|c|}
\hline 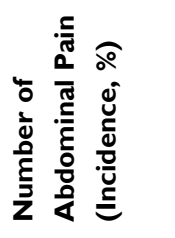 & $\frac{\alpha}{Z}$ & $\frac{\alpha}{z}$ & $\frac{o}{z}$ & $\frac{\alpha}{z}$ & $\stackrel{\alpha}{z}$ & $\stackrel{\alpha}{Z}$ & $\frac{\mathscr{O}}{z}$ & $\stackrel{\alpha}{Z}$ & $\stackrel{\alpha}{Z}$ & $\frac{\mathscr{N}}{z}$ & ذેं & $\stackrel{\text { 号 }}{Z}$ & $\stackrel{\stackrel{\circ}{F}}{\stackrel{+}{*}}$ & $\frac{\alpha}{Z}$ & $\frac{\alpha}{Z}$ & $\frac{\alpha}{z}$ & $\frac{\alpha}{z}$ & $\frac{\alpha}{z}$ & $\stackrel{\alpha}{z}$ \\
\hline 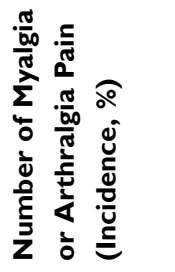 & $\frac{o}{Z}$ & 固 & $\stackrel{\stackrel{\circ}{\Xi}}{=}$ & $\frac{\mathscr{N}}{Z}$ & $\begin{array}{l}\stackrel{\circ}{\infty} \\
\stackrel{\sim}{\sim}\end{array}$ & $\frac{\mathscr{O}}{Z}$ & 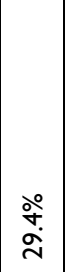 & $\stackrel{\alpha}{z}$ & $\frac{o}{z}$ & 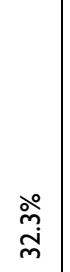 & $\stackrel{\stackrel{\circ}{+}}{+}$ & $\frac{\stackrel{\circ}{\circ}}{\stackrel{\infty}{\infty}}$ & $\stackrel{\mathscr{c}}{Z}$ & $\begin{array}{l}\stackrel{\circ}{\circ} \\
\stackrel{+}{*}\end{array}$ & $\begin{array}{l}\text { ○̊ } \\
\text { సે }\end{array}$ & $\stackrel{\stackrel{\circ}{\stackrel{\circ}{\Lambda}}}{=}$ & $\stackrel{\mathscr{O}}{Z}$ & 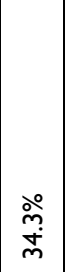 & $\underline{\alpha}$ \\
\hline 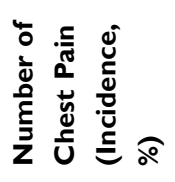 & $\frac{\alpha}{z}$ & $\frac{\alpha}{z}$ & ○ें & 品 & $\frac{\alpha}{z}$ & $\stackrel{\alpha}{Z}$ & $\stackrel{\circ}{\stackrel{0}{人}}$ & $\stackrel{\alpha}{Z}$ & $\stackrel{\alpha}{Z}$ & $\stackrel{\alpha}{z}$ & $\frac{\alpha}{Z}$ & ठ̊. & $\stackrel{\alpha}{Z}$ & 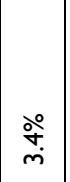 & $\frac{\alpha}{Z}$ & $\frac{\alpha}{z}$ & $\frac{\alpha}{z}$ & $\frac{\alpha}{z}$ & $\frac{\alpha}{Z}$ \\
\hline 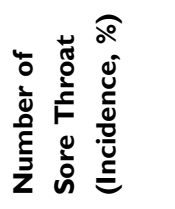 & よ̊ & $\frac{\alpha}{Z}$ & $\frac{\circ}{\dot{n}}$ & ڤั่ & $\begin{array}{l}\stackrel{\circ}{\circ} \\
\stackrel{\sim}{\oplus}\end{array}$ & $\stackrel{o}{Z}$ & $\frac{\stackrel{\circ}{\vec{r}}}{\stackrel{\vec{f}}{*}}$ & $\stackrel{\alpha}{z}$ & $\stackrel{\circ}{\stackrel{\circ}{=}}$ & $\stackrel{o}{Z}$ & 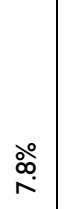 & $\frac{o}{Z}$ & $\begin{array}{l}\stackrel{\circ}{\text { i̊n }} \\
\stackrel{+}{+}\end{array}$ & $\stackrel{\circ}{\stackrel{\circ}{\circ}}$ & $\frac{\alpha}{Z}$ & $\begin{array}{l}\stackrel{\circ}{\stackrel{0}{ \pm}} \\
\stackrel{ \pm}{ \pm}\end{array}$ & $\stackrel{\circ}{\stackrel{\circ}{~}}$ & $\stackrel{\alpha}{z}$ & 응 \\
\hline 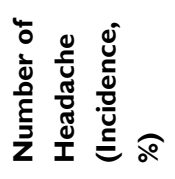 & $\stackrel{o}{z}$ & $\stackrel{\circ}{\stackrel{2}{\wedge}}$ & $\frac{\circ}{\infty}$ & $\begin{array}{l}\stackrel{\circ}{\sigma} \\
\text { å }\end{array}$ & 宇 & $\frac{\circ}{\dot{m}}$ & $\frac{o}{z}$ & خें & $\frac{\alpha}{Z}$ & $\stackrel{\alpha}{Z}$ & $\underset{\stackrel{\circ}{+}}{\stackrel{\circ}{+}}$ & $\begin{array}{l}\stackrel{\circ}{\infty} \\
\stackrel{0}{0}\end{array}$ & $\stackrel{\circ}{\stackrel{\circ}{\underline{m}}}$ & $\stackrel{\text { ণิ }}{\text { ஸे }}$ & $\frac{o}{z}$ & $\begin{array}{l}\stackrel{\circ}{+} \\
\stackrel{\leftrightarrow}{\underline{j}}\end{array}$ & $\frac{\alpha}{z}$ & $\stackrel{\alpha}{z}$ & $\begin{array}{l}\stackrel{\circ}{m} \\
\stackrel{\sim}{\sim}\end{array}$ \\
\hline 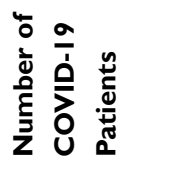 & $\bar{n}$ & $\bar{\sigma}$ & $\sigma$ & $\stackrel{\infty}{m}$ & ㅇ & $\approx$ & $\stackrel{\circ}{m}$ & $\bar{\infty}$ & $\overline{\underline{ }}$ & $\bar{i}$ & ঃ & $\cong$ & $\frac{\nabla}{N}$ & $\frac{\circ}{\sigma}$ & $\begin{array}{l}\stackrel{ \pm}{\stackrel{m}{m}} \\
\stackrel{=}{=}\end{array}$ & 용 & $\stackrel{\Xi}{=}$ & $\underline{\underline{\delta}}$ & $\stackrel{\text { I }}{1}$ \\
\hline 辛 & 䄈 & 莺 & 莺 & 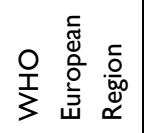 & 祬 & $\stackrel{\widetilde{s}}{\bar{U}}$ & 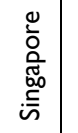 & 苞 & $\stackrel{\tilde{E}}{\tilde{\epsilon}}$ & $\stackrel{\mathscr{c}}{\tilde{U}}$ & 㞼 & 趇 & 营 & 离 & 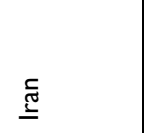 & 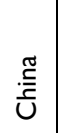 & $\stackrel{\frac{\tilde{g}}{\tilde{E}}}{\mathrm{E}}$ & 䒿 & 疍 \\
\hline 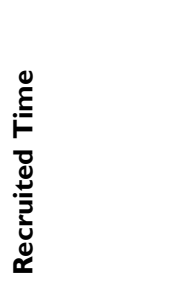 & 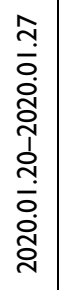 & 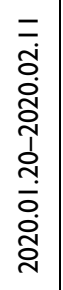 & 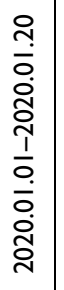 & 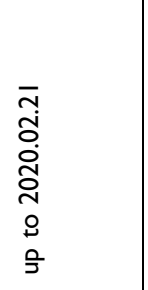 & 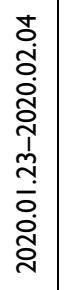 & 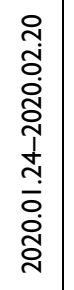 & 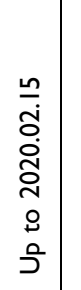 & 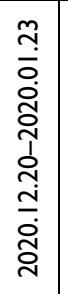 & 产 & 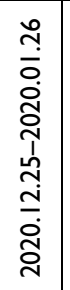 & 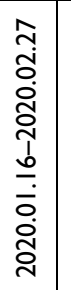 & 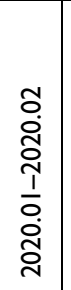 & 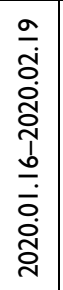 & 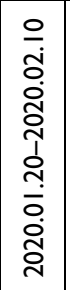 & 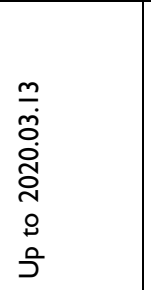 & 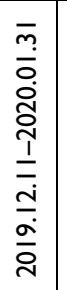 & 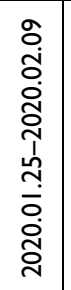 & 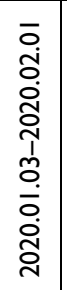 & 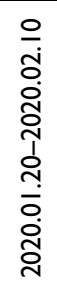 \\
\hline 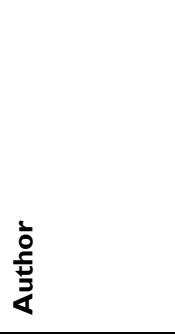 & $\begin{array}{l}\cong \\
\vdots \\
\vdots \\
0 \\
0\end{array}$ & $\begin{array}{l}\stackrel{m}{=} \\
\dot{\tilde{\sigma}} \\
\overline{0}\end{array}$ & $\begin{array}{l}\overline{\bar{v}} \\
\overline{\bar{v}} \\
\frac{\tilde{U}}{}\end{array}$ & 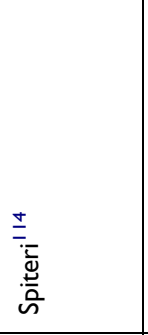 & $\stackrel{n}{\bar{x}}$ & $\begin{array}{l}\stackrel{0}{\bar{n}} \\
\stackrel{3}{N}\end{array}$ & $\begin{array}{lll}\tilde{n}_{00} & \\
\mathfrak{n}_{00} & \vdots \\
0 & \end{array}$ & $\overline{\overline{i \bar{n}}}$ & $\begin{array}{l}\stackrel{\infty}{=} \\
\frac{0}{N} \\
\text { N }\end{array}$ & $\stackrel{\frac{9}{3}}{3}$ & 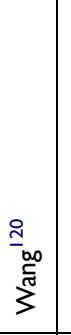 & ב & $\begin{array}{l}\overline{\underline{I}} \\
\bar{g}\end{array}$ & 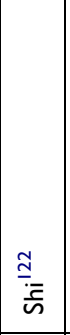 & 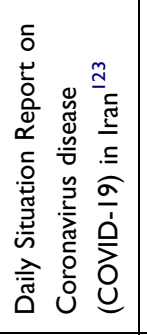 & 管 & 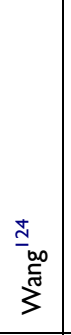 & $\stackrel{\stackrel{\sim}{\mathcal{g}}}{\tilde{d}}$ & 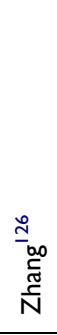 \\
\hline 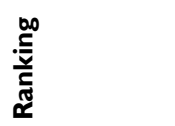 & $\bar{\sim}$ & $\approx$ & $\approx$ & $\stackrel{\sim}{\sim}$ & $\stackrel{\sim}{\sim}$ & $\stackrel{\sim}{2}$ & $\hat{\lambda}$ & $\stackrel{\infty}{\sim}$ & సి & 이 & $\bar{m}$ & $\tilde{m}$ & $\stackrel{m}{m}$ & $\dot{m}$ & $\stackrel{m}{m}$ & ల్ల & $\hat{m}$ & $\stackrel{\infty}{\infty}$ & 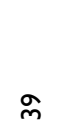 \\
\hline
\end{tabular}




\begin{tabular}{|c|c|c|c|c|c|c|c|c|c|c|c|c|c|c|}
\hline 号 & 号 & 足 & $\stackrel{\alpha}{Z}$ & $\frac{\alpha}{z}$ & 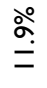 & 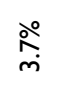 & $\begin{array}{l}\stackrel{\circ}{\circ} \\
\text { ì }\end{array}$ & $\frac{\alpha}{z}$ & 孚 & 号 & 営 & $\frac{\alpha}{z}$ & $\frac{\alpha}{z}$ & ํํํ \\
\hline 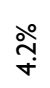 & 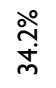 & $\stackrel{\alpha}{Z}$ & $\stackrel{\alpha}{Z}$ & $\stackrel{\alpha}{Z}$ & 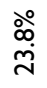 & $\begin{array}{l}\stackrel{0}{\circ} \\
\text { ف }\end{array}$ & 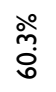 & $\stackrel{\text { స్ }}{\text { ’े }}$ & $\stackrel{\stackrel{\circ}{\leftarrow}}{\stackrel{\circ}{=}}$ & $\begin{array}{l}\text { مे } \\
\text { 음 }\end{array}$ & ํํํ & $\stackrel{\text { @̊ }}{\text { İ }}$ & $\stackrel{\text { 을 }}{=}$ & $\begin{array}{l}\text { ㅇํํ } \\
\text { 응 }\end{array}$ \\
\hline$\frac{\alpha}{Z}$ & $\frac{\alpha}{z}$ & $\stackrel{\alpha}{Z}$ & $\stackrel{\alpha}{Z}$ & 号 & $\stackrel{\alpha}{Z}$ & $\frac{\alpha}{z}$ & 足 & ف요 & $\frac{\alpha}{Z}$ & $\frac{\alpha}{z}$ & $\stackrel{\alpha}{Z}$ & $\begin{array}{c}\stackrel{\circ}{\infty} \underset{+}{\infty} \\
\dot{+}\end{array}$ & 兑 & $\stackrel{\text { ণे }}{\mathrm{d}}$ \\
\hline$\stackrel{\alpha}{Z}$ & $\underline{\alpha}$ & $\stackrel{\stackrel{\circ}{m}}{\stackrel{m}{m}}$ & $\underset{\infty}{\stackrel{\infty}{0}}$ & ફ̊ & 总 & 犬े & $\frac{\alpha}{z}$ & $\begin{array}{l}\stackrel{\circ}{\circ} \\
\stackrel{\leftrightarrow}{2}\end{array}$ & $\frac{\alpha}{z}$ & $\frac{\circ}{\sigma}$ & $\frac{o}{Z}$ & $\frac{\stackrel{\circ}{\infty}}{\infty}$ & $\stackrel{\alpha}{z}$ & $\stackrel{\stackrel{\circ}{\sim}}{\text { d }}$ \\
\hline 只 & $\frac{\alpha}{z}$ & 足 & $\frac{\alpha}{Z}$ & $\stackrel{\circ}{\stackrel{2}{x}}$ & $\stackrel{\alpha}{Z}$ & $\begin{array}{l}\text { 今े } \\
\text { 을 }\end{array}$ & $\stackrel{\alpha}{Z}$ & $\frac{\alpha}{z}$ & $\stackrel{\circ}{\stackrel{\circ}{~}}$ & $\stackrel{\stackrel{\circ}{\stackrel{\circ}{=}}}{=}$ & 兑 & $\stackrel{\alpha}{Z}$ & $\stackrel{\circ}{\stackrel{\circ}{n}}$ & 兑 \\
\hline$\stackrel{\infty}{+}$ & $\stackrel{n}{n}$ & 亡े & $\stackrel{\circ}{ }$ & $\stackrel{\infty}{\text { N }}$ & $\mathcal{F}$ & 드 & 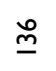 & $\stackrel{\sim}{\underline{D}}$ & 으 & 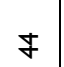 & $\overline{\underline{m}}$ & $\stackrel{\circ}{f}$ & $\underline{\sigma}$ & $\stackrel{\infty}{\infty}$ \\
\hline 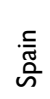 & $\stackrel{\frac{\pi}{\tilde{U}}}{\tilde{U}}$ & $\frac{1}{\overline{5}}$ & 茎 & 䒜 & 蒙 & 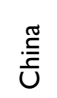 & 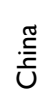 & : & 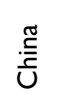 & : & & & 䋃 & 胥 \\
\hline 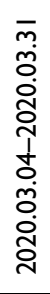 & 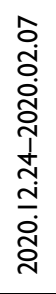 & 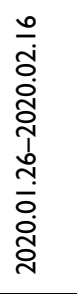 & 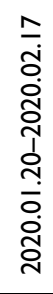 & 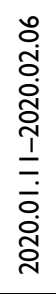 & 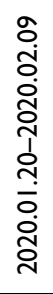 & 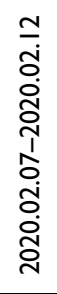 & 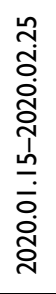 & 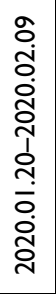 & 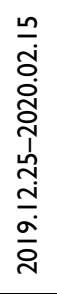 & 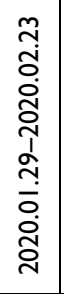 & 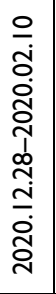 & 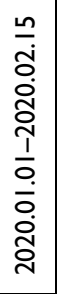 & 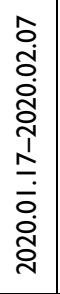 & 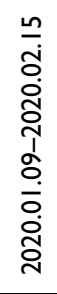 \\
\hline 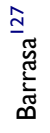 & 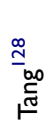 & 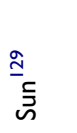 & 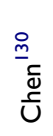 & רָּ & $\begin{array}{l}\overline{\bar{m}} \\
\overline{\bar{v}} \\
\bar{U}\end{array}$ & 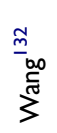 & 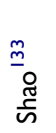 & 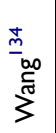 & 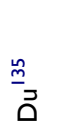 & 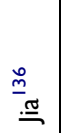 & בּَْ & 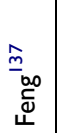 & 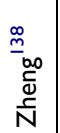 & $\frac{\stackrel{\alpha}{\underline{m}}}{\vec{a}}$ \\
\hline 우 & $\bar{\gamma}$ & $\mathcal{F}$ & $q$ & $\forall$ & ஜே & fo & $\hat{f}$ & $\stackrel{\infty}{+}$ & 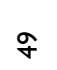 & in & $\bar{n}$ & กิ & nิ & 苛 \\
\hline
\end{tabular}




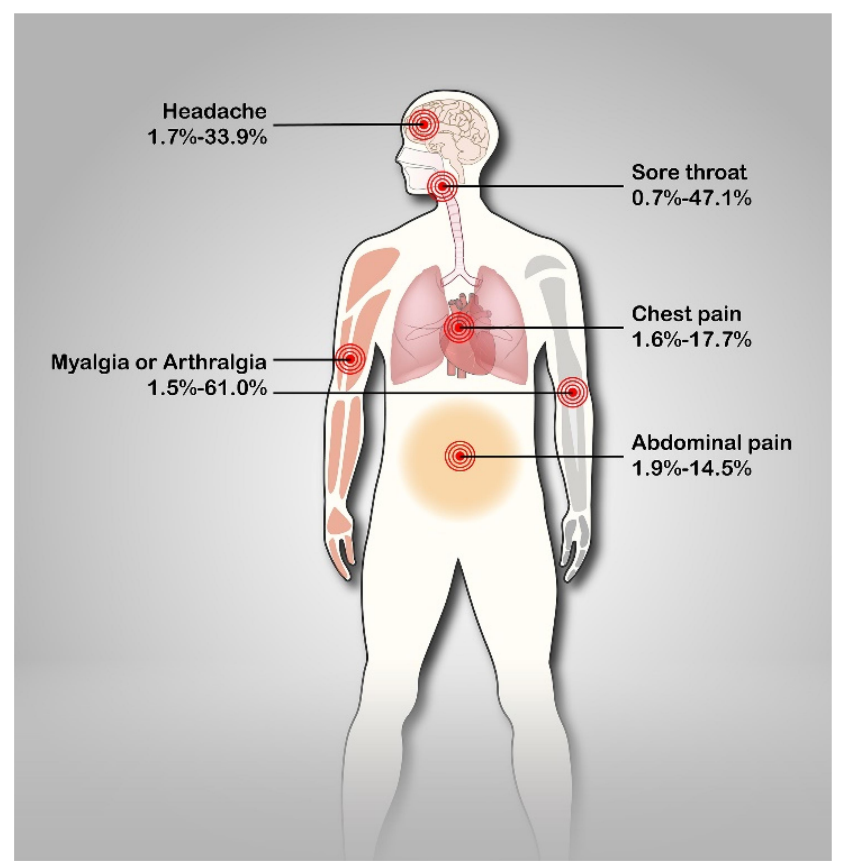

Figure I The incidence rate of pain symptoms for patients with COVID-19.

still many infection sites indirectly connected to the olfactory bulb, indicating body fluid pathway for viral infection (such as blood, lymph and cerebral spinal fluid). ${ }^{35,39}$ SARS-CoV-2 has the same functional receptor as SARSCoV - ACE2. ${ }^{40}$ The significant presence of blood and lymphatic capillaries in the nasal mucosa provides a favorable environment for the virus invasion and help to enter the blood stream after interaction with ACE2 expressed on endothelial cells. When the virus spreads in the respiratory tract, it can also bind to ACE2 expressed on the epithelial cells and enter the blood stream. SARS-CoV -2 can spread to the CNS through vascular pathways. Likewise, the virus in the gastrointestinal tract can also enter the CNS through blood vessels, lymphoid pathways, and the vagus nerve. ${ }^{39}$

Headache is not a typical symptom of patients with COVID-19, but it cannot be easily ignored. A confirmed case reported that he only experienced strong headache and fatigue, without fever, coughing or breathing problems in the early days. Then, he displayed anosmia and slowly emerged common symptoms. ${ }^{41}$ This condition indicates that headache and anosmia are the early signs of COVID-19 in some patients. Doctors should also focus on patients who report early neurological symptoms, because the virus shows a potential neurotropism, and may eliminate medullary neurons and threaten the patient's life during the incubation period. ${ }^{42}$ In addition,
$\mathrm{Hu}$ et al found that headache was a predictor of intermittent negative state in patients with COVID-19, with probability of $60 \%$. Intermittent negative status was described as COVID-19 patient who showed negative on reversetranscription-polymerase-chain-reaction test was redetected virus RNA. It showed that a large proportion of patients with headache had delayed clearance of SARSCoV-2 and poor prognosis, suggesting doctors still give attention to patients who tested negative with COVID-19, and prolong their isolation and hospitalization. ${ }^{43}$

\section{Sore Throat}

Sore throat refers to the pain caused by inflammation of tissues located behind the throat, ${ }^{44}$ and up to $80 \%$ of the cases is caused by viruses (eg, coronavirus, influenza, and rhinovirus). ${ }^{45,46}$ Internationally, sore throat complaints account for $1-4 \%$ of all primary care reports. ${ }^{47}$ Within a year, approximately $30 \%$ of the general population experiences sore throat once because of viral infection, and the course is usually self-limited. ${ }^{48}$ Patients with sore throat may also experience redness, swelling, scratchy, coughing, and hoarseness. ${ }^{49,50}$ In China, Guan et al described the clinical characteristics of 1099 patients with COVID-19 in a selected cohort on 29 January 2020. A total of 153 patients reported sore throat, and the incidence rate was approximately 13.9\%. ${ }^{9}$ On 1-30 March 2020, Garg et al collected data from 1482 hospitalized patients with COVID-19 in the United States. The symptoms of 180 adults were presented using the COVID-19-associated hospitalization surveillance network, sore throat was $17.8 \%(n=32) .{ }^{51}$ Table 1 shows that the incidence rate of sore throat is $0.7-47.1 \%$ (Figure 1 ). ${ }^{27,52}$

At present, few studies have clearly explained the mechanism for the development of sore throat in patients with COVID-19. Given that both SARS-CoV-2 and influenza virus can spread in the respiratory tract and exhibit similar symptoms, ${ }^{53,54}$ we speculate that the reason of sore throat induced by influenza may be applicable to SARS-CoV -2 . The body may release inflammatory mediators (eg, prostaglandins and bradykinin) in the airway in response to SARS-CoV-2 infection, thereby affecting the sensory nerve in the layers of throat tissue and causing sore throat. ${ }^{30,50}$

Sore throat is one of the common otorhinolaryngological dysfunctions in patients with COVID-19. Krajewska et al discussed the connection between otorhinolaryngological manifestations and patients with COVID-19 in a review. She mentioned that sore throat, cough, and dyspnea were often observed in young, mildly, or moderately ill patients with COVID-19. Before the confirmation 
of SARS-CoV-2 in molecular analysis, patients may present these symptoms. ${ }^{55}$ Yan et al also reported that patients who tested negative with COVID-19 are 4-5 times more likely to develop sore throat than those who tested positive with COVID-19. ${ }^{56}$ Sore throat is not as common as fever in patients with COVID-19, but these patients should still be considered as carrier of COVID-19. In comparison with elderly patients infected with coronavirus, young adults have a higher incidence of sore throat. ${ }^{57,58}$ This condition may also be a common feature of COVID-19.

\section{Myalgia or Arthralgia}

Myalgia is a symptom of muscle pain or discomfort, and it is mostly caused by systemic or local infection. ${ }^{59,60}$ It is usually diffuse rather than localized and is likely to cause referred pain. ${ }^{61}$ Arthralgia is defined as joint pain or stiffness ${ }^{62}$ that results in low quality of life, adverse emotions, reduced compliance, and even interruption of treatment. ${ }^{63,64}$ Both myalgia and arthralgia belong to musculoskeletal pain, which is experienced by most people at least once in a lifetime, thus negatively affecting their physical, social and psychological levels. $^{65}$ In an epidemiological and clinical investigation, Pung et al analyzed 36 cases of COVID-19 until 15 February 2020 in Singapore. Among the 17 local patients who tested positive for SARS-CoV-2, myalgia was reported in 14 (29.4\%) individuals. ${ }^{52}$ Mo et al retrospectively analyzed the characteristics of confirmed cases in China, including 155 patients with COVID-19 from 1 January 2020 to 5 February 2020. Fifty patients experienced myalgia or arthralgia, accounting for $61.0 \%$ of 82 patients with valid data. ${ }^{34}$ Table 1 shows that the incidence rate range of myalgia/arthralgia is $1.5-61.0 \%$ (Figure 1). ${ }^{34,66}$ Myalgia during viral infection is usually mediated by interleukin-6, which upregulates and causes myalgia or arthralgia. ${ }^{67,68}$ Creatine kinase (CK) and lactate dehydrogenase (LDH) can assess skeletal muscle damage. $^{69}$ Mao et al found that patients with COVID-19 having muscle symptoms had higher levels of CK and LDH than those without muscle symptoms. Myalgia might be caused by skeletal muscle injury. ${ }^{40}$ ACE2 is also present in skeletal muscle, ${ }^{70}$ and SARS-CoV-2 may bind with ACE2 to infect skeletal muscle. However, the autopsy result of SARS$\mathrm{CoV}$-infected patients did not indicate SARS-CoV infection in skeletal muscle. ${ }^{71}$ Hence, the mechanism still needs further study. Second, myalgia may also occur when cytokines stimulate the production of prostaglandin E2, and prostaglandin E2 mediate pain via peripheral pain receptors. ${ }^{30}$ In addition, skeletal muscle injury is also a manifestation of nervous system damage. $^{40}$ SARS-CoV-2 can invade the central nervous system through peripheral nerves or directly attack the nervous system by binding to ACE2 to cause skeletal muscle injury.

Myalgia is closely related to SARS-CoV-2 test positivity and can be used as one of the strongest predictors. ${ }^{72}$ General myalgia is very common in patients with COVID-19, but focal myalgia should alert the doctor that the patient may have rhabdomyolysis. ${ }^{73}$ Rhabdomyolysis is a potentially fatal syndrome, and its important indices are the concentration of serum CK or appearance of myoglobinuria. ${ }^{74}$ The CK level may indicate the severity of rhabdomyolysis. ${ }^{75}$ In comparison with non-severely infected patients, patients with severe infection have higher levels of $\mathrm{CK}$ and $\mathrm{LDH}^{40}$ Therefore, the severity of myalgia may predict the severity of COVID-19 infection. Arthralgia is not a common symptom, and approximately $2.5 \%$ of patients with COVID-19 presented joint pain in Thailand up to 28 February $2020 .^{76}$ Doctors should not ignore arthralgia when diagnosing COVID-19 to avoid misdiagnosis.

\section{Chest Pain}

Chest pain refers to discomfort or pain between the neck and upper abdomen. During a lifetime, this condition affects $20-40 \%$ of the general population. Moreover, patients with chest pain often suffer from health-related

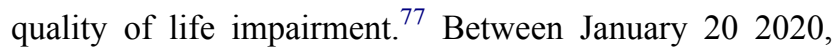
and February 10 2020, Shi et al conducted a retrospective cohort study that included 416 confirmed COVID-19 cases in Wuhan, China. Fourteen patients experienced chest pain, accounting for $13.4 \%{ }^{78}$ Up to 29 March 2020, the COVID-19 National Incident Room Surveillance Team reported 4159 confirmed cases in Australia. Among the 2257 patients with COVID-19 who reported symptoms, $5 \%$ experienced chest pain. ${ }^{79}$ Table 1 shows that the incidence rate range of chest pain is $1.6-17.7 \%$ (Figure 1). ${ }^{52,80}$

The mechanism of chest pain caused by the invasion of the SARS-CoV-2 remains unclear. We speculate that chest pain may result from cardiac injury or pleural inflammatory infection. $^{12,78}$ A high ACE2 expression has been observed in the heart. ${ }^{70}$ The result of autopsy in patients who died from SARS revealed SARS-CoV viral RNA in the heart samples. ${ }^{81}$ This finding indicates that the virus mediated by ACE2 can invade cardiomyocytes directly and cause cardiac injury. Moreover, the inflammatory markers (eg, C-reactive protein, leukocytes, and procalcitonin), which may be due to the cytokine storm syndrome, increase substantially in patients with cardiac injury. The enhanced release and activation of inflammatory cytokines can damage myocardial cells. ${ }^{78}$ Furthermore, some inflammatory mediators released into the 
pleural space can trigger pain receptors on the pleura, thus causing chest pain. ${ }^{82}$ In addition, cardiac injury can be attributed to respiratory dysfunction and hypoxemia instigated by COVID-19. ${ }^{83}$

The symptoms of chest pain and dyspnea represent severe COVID-19. ${ }^{84}$ In comparison with general patients, severe/ critical patients have higher incidence of chest pain; ${ }^{12}$ in comparison with survivors, the prevalence of chest pain in nonsurvivors is approximately three times higher. ${ }^{84}$ Therefore, chest pain may be a risk factor for developing severe/critical COVID-19 or death. The National Health Commission of China reported that $11.8 \%$ of non-survivors without underlying cardiovascular disease had severe heart injury. ${ }^{83}$ In patients infected with SARS-CoV-2, cardiovascular disease has high incidence and can easily lead to deterioration. In addition, $\mathrm{Wu}$ et al recruited 25 SARS survivors in 2014 and found that SARS-CoV could cause long-term damage to the patient's cardiovascular system. ${ }^{85}$ It indicates that recovered patients with COVID-19 are likely to have sequelae of the cardiovascular system. For patients with chest pain, doctors should keep alert and not neglect the cardiovascular protection during treatment.

\section{Abdominal Pain}

Abdominal pain is the symptom of disordered gastrointestinal motility and sensation that affects almost everyone once in a lifetime. ${ }^{86,87}$ This condition is associated with complications (eg, depression, anxiety, fibromyalgia) and the decline in the quality of life. ${ }^{87,88}$ Qin et al completed a retrospective study and recruited 452 confirmed patients with COVID-19 between 10 January 2020 and 12 February 2020 in Wuhan, China. Among these patients, 23 cases involved abdominal pain, and the incidence rate was $5.1 \%{ }^{28}$ To explore the clinical characteristics and allergy status of patients with COVID-19, Zhang et al investigated the medical records of 140 confirmed patients in the No. 7 Hospital of Wuhan in China. Eight patients presented abdominal pain in the 139 valid data, and the incidence rate was $5.8 \%{ }^{89}$ Table 1 shows that the incidence rate range of abdominal pain is $1.9-14.5 \%$ (Figure 1). ${ }^{34,90}$

Few studies have clearly explained the mechanism of abdominal pain caused by SARS-CoV-2. Of 1141 confirmed patients with COVID-19 in China, Luo et al found $183(16 \%)$ cases had gastrointestinal symptoms only, of which $25 \%$ presented abdominal pain. ${ }^{91}$ It indicates that SARS-CoV-2 invades the gastrointestinal tract and caused abdominal pain. ACE2 is abundantly expressed in the gastrointestinal tract, especially in the small and large intestines. ${ }^{92,93}$ Therefore, SARS-CoV-2 can attack the digestive system by combing with ACE2 and cause pain. In children, pneumonia is the most common extra-abdominal cause of abdominal pain. The enlarged mesenteric lymph nodes are considered a potential mechanism in the presence of abdominal pain in children with pneumonia. ${ }^{94}$ However, further research is needed on whether this mechanism is applicable to adult patients with COVID-19.

In comparison with non-severely infected patients, patients with severe infection more likely to report abdominal pain. Patients without digestive symptoms usually have better prognosis than those with digestive symptoms. ${ }^{95}$ In addition, based on the review of the medical records of Oslo University Hospital during the outbreak of acute abdominal pain, 76 patients came to the hospital with the chief complaint of acute abdominal pain, and nine patients were diagnosed with COVID-19 (11.8\%). ${ }^{96}$ At the early stage of the epidemic, some patients may only report atypical symptoms but should still be suspected of being potential patients with COVID-19. It suggested that patients with symptoms of abdominal pain should also be diagnosed with oropharyngeal and nasopharyngeal swabs. On the other hand, it has been reported that confirmed cases tested positive for SARS-CoV-2 RNA in stool specimens, indicating that individuals could be infected via the fecal-oral route. ${ }^{97}$ SARS-CoV-2 is highly contagious, suggesting that everyone should wash their hands before and after going to the toilet and not touch mucous membranes, such as nose and eyes, with dirty hands. Patients with COVID-19 should use a single toilet in the quarantine area and dispose their waste properly as directed by the appropriate authorities. $^{95}$

\section{Conclusion}

In summary, the virus not only invades the respiratory system and cause fever, cough, sore throat, and other pneumoniaassociated symptoms, but also infects other systems in humans and results in corresponding symptoms, including nervous system (eg, headache, dizziness, and confusion), digestive system (eg, diarrhea, abdominal pain, and loss of appetite), and cardiovascular system (eg, palmus, chest pain, and cardiac injury). ${ }^{10,11}$ Chest pain, myalgia, and abdominal pain are likely to occur in patients with severe infections, foreshadowing a wider range of virus invasion. These conditions may be risk factors for developing severe or critical COVID-19. Sore throat is more common in mild patients than in severe patients. It may be attributed to the invasion of the virus is limited to respiratory system in mild patients, and other systems are not damaged. Moreover, the spread of the virus through feces also suggests that need for more effective 
protective measures to prevent further spread of COVID-19 and control infection. The incidence rate is $1.7-33.9 \%$ for headache, $0.7-47.1 \%$ for sore throat, $1.5-61.0 \%$ for myalgia/ arthralgia, $1.6-17.7 \%$ for chest pain, and $1.9-14.5 \%$ for abdominal pain. Different pain reflects the damage of different body systems. However, pain in patients with COVID-19 may also be caused by treatment-related persistent pain and discomfort, intermittent procedural pain, and chronic pain before admission to the intensive care unit. ${ }^{68}$ So, it is particularly important to determine the source of pain in the long and complicated treatment process. Although these pain symptoms are not as typical as fever and cough, doctors should not ignore them to avoid misdiagnosis or delayed diagnosis. They are also the signal that could alert doctors to pay attention to strengthen self-protection to reduce infection risks. The symptoms can also provide basis for doctors to take more targeted measures, treat and cure patients reasonably. In addition, once the general population has these symptoms, they should also consider that they are potential patients with COVID-19, should isolate themselves and seek medical attention as soon as possible.

\section{Abbreviations}

SARS, severe acute respiratory syndrome; MERS-COV, Middle East respiratory syndrome coronavirus; CNS, central nervous system; ACE2, angiotensin converting enzyme 2; $\mathrm{CK}$, creatine kinase; LDH, lactate dehydrogenase.

\section{Data Sharing Statement}

All data generated or analysed during this study are included in this published article.

\section{Acknowledgments}

We would like to express our appreciation and respect to the frontline medical workers fighting Covid-19 pandemic.

\section{Funding}

This work was supported by Fok Ying-Tong Education Foundation of China (161092); The scientific and technological research program of the Shanghai Science and Technology Committee (Fund number: 19080503100); the Shanghai Key Lab of Human Performance (Shanghai University of Sport) (11DZ2261100).

\section{Disclosure}

The authors report no conflicts of interest in this work.

\section{References}

1. WHO. WHO Director-General's opening remarks at the media briefing on COVID-19-11 March 2020; 2020. Available from: https://www.who.int/dg/speeches/detail/who-director-general -s-opening-remarks-at-the-media-briefing-on-covid-19-11march-2020.

2. WHO. Coronavirus disease (COVID-2019) situation reports; 2020. Available from: https://www.who.int/emergencies/diseases/ novel-coronavirus-2019/situation-reports. Accessed January 13, 2021.

3. Remuzzi A, Remuzzi G. COVID-19 and Italy: what next? Lancet. 2020;395(10231):1225-1228. doi:10.1016/S0140-6736(20) 30627-9

4. Zhang H, Tang K, Fang R, Sun Q. What dermatologists could do to cope with the novel coronavirus (SARS-CoV-2): a dermatologist's perspective from China. $J$ Eur Acad Dermatol Venereol. 2020;34. doi:10.1111/jdv.16389

5. Bayham J, Fenichel EP. Impact of school closures for COVID-19 on the US health-care workforce and net mortality: a modelling study. Lancet Public Health. 2020;5:e271-e278. doi:10.1016/ S2468-2667(20)30082-7

6. Brooks SK, Webster RK, Smith LE, et al. The psychological impact of quarantine and how to reduce it: rapid review of the evidence. Lancet. 2020;395(10227):912-920. doi:10.1016/S01406736(20)30460-8

7. Cavallo JJ, Forman HP. The economic impact of the COVID-19 pandemic on radiology practices. Radiology. 2020;296:201495. doi:10.1148/radiol.2020201495

8. Chow EJ, Schwartz NG, Tobolowsky FA, et al. Symptom screening at illness onset of health care personnel with SARS-CoV-2 infection in King County, Washington. JAMA. 2020;323:2087. doi:10.1001/jama.2020.6637

9. Guan WJ, Ni ZY, Hu Y, et al. Clinical characteristics of coronavirus disease 2019 in China. $N$ Engl J Med. 2020;382:1708-1720.

10. Huang C, Wang Y, Li X, et al. Clinical features of patients infected with 2019 novel coronavirus in Wuhan, China. Lancet. 2020;395(10223):497-506. doi:10.1016/S0140-6736(20)30183-5

11. Chen N, Zhou M, Dong X, et al. Epidemiological and clinical characteristics of 99 cases of 2019 novel coronavirus pneumonia in Wuhan, China: a descriptive study. Lancet. 2020;395 (10223):507-513. doi:10.1016/S0140-6736(20)30211-7

12. $\mathrm{Li} \mathrm{K}, \mathrm{Wu} \mathrm{J}, \mathrm{Wu} \mathrm{F}$, et al. The clinical and chest $\mathrm{CT}$ features associated with severe and critical COVID-19 pneumonia. Invest Radiol. 2020;55:327-331. doi:10.1097/ RLI.000000000000672

13. Cheung KS, Hung IF, Chan PP, et al. Gastrointestinal manifestations of SARS-CoV-2 infection and virus load in fecal samples from the Hong Kong cohort and systematic review and meta-analysis. Gastroenterology. 2020.

14. Pan L, Mu M, Yang P, et al. Clinical characteristics of COVID-19 patients with digestive symptoms in Hubei, China: a descriptive, cross-sectional, multicenter study. Am $J$ Gastroenterol. 2020;115:766-773. doi:10.14309/ajg.0000000000000620

15. Zhu J, Ji P, Pang J, et al. Clinical characteristics of 3062 COVID-19 patients: a meta-analysis. J Med Virol. 2020.

16. $\mathrm{Xu} \mathrm{XW}, \mathrm{Wu} \mathrm{XX}$, Jiang $\mathrm{XG}$, et al. Clinical findings in a group of patients infected with the 2019 novel coronavirus (SARS-Cov-2) outside of Wuhan, China: retrospective case series. BMJ. 2020;368:m606. doi:10.1136/bmj.m606

17. Chen $\mathrm{H}$, Guo J, Wang $\mathrm{C}$, et al. Clinical characteristics and intrauterine vertical transmission potential of COVID-19 infection in nine pregnant women: a retrospective review of medical records. Lancet. 2020;395(10226):809-815. doi:10.1016/S01406736(20)30360-3 
18. Booth CM, Matukas LM, Tomlinson GA, et al. Clinical features and short-term outcomes of 144 patients with SARS in the greater Toronto area. JAMA. 2003;289(21):2801-2809. doi:10.1001/ jama.289.21.JOC30885

19. Choi KW, Chau TN, Tsang O, et al. Outcomes and prognostic factors in 267 patients with severe acute respiratory syndrome in Hong Kong. Ann Intern Med. 2003;139(9):715-723. doi:10.7326/ 0003-4819-139-9-200311040-00005

20. Lee $\mathrm{N}$, Hui $\mathrm{D}, \mathrm{Wu} \mathrm{A}$, et al. A major outbreak of severe acute respiratory syndrome in Hong Kong. $N$ Engl J Med. 2003;348 (20):1986-1994. doi:10.1056/NEJMoa030685

21. Tsang KW, Ho PL, Ooi GC, et al. A cluster of cases of severe acute respiratory syndrome in Hong Kong. $N$ Engl J Med. 2003;348(20):1977-1985. doi:10.1056/NEJMoa030666

22. Onwuchekwa CR, Onwuchekwa AC. The role of computed tomography in the diagnostic work-up of headache patients in Nigeria. Headache. 2010;50(8):1346-1352. doi:10.1111/j.15264610.2010.01712.x

23. Stovner L, Hagen K, Jensen R, et al. The global burden of headache: a documentation of headache prevalence and disability worldwide. Cephalalgia. 2007;27(3):193-210. doi:10.1111/ j.1468-2982.2007.01288.x

24. Jensen R, Stovner LJ. Epidemiology and comorbidity of headache. Lancet Neurol. 2008;7(4):354-361. doi:10.1016/ S1474-4422(08)70062-0

25. Guan WJ, Liang WH, Zhao Y, et al. Comorbidity and its impact on 1590 patients with Covid-19 in China: a nationwide analysis. Eur Respir J. 2020;55:2000547. doi:10.1183/13993003.005472020

26. COVID-19 National Incident Room Surveillance Team. COVID-19, Australia: epidemiology report 11 (Reporting week to 23:59 AEST 12 April 2020). Commun Dis Intell (2018). 2020;44.

27. Cai Q, Huang D, Ou P, et al. COVID-19 in a designated infectious diseases hospital outside Hubei Province, China. Allergy. 2020;75:1742-1752. doi:10.1111/all.14309

28. Qin C, Zhou L, Hu Z, et al. Dysregulation of immune response in patients with coronavirus 2019 (COVID-19) in Wuhan, China. Clin Infect Dis. 2020;71(15):762-768. doi:10.1093/cid/ciaa248

29. Neurath MF. Covid-19 and immunomodulation in IBD. Gut. 2020;69:1335-1342. doi:10.1136/gutjnl-2020-321269

30. Eccles R. Understanding the symptoms of the common cold and influenza. Lancet Infect Dis. 2005;5(11):718-725. doi:10.1016/ S1473-3099(05)70270-X

31. Marchioni E, Minoli L. Headache attributed to infections nosography and differential diagnosis. Handb Clin Neurol. 2010;97:601-626.

32. Wu Y, Xu X, Chen Z, et al. Nervous system involvement after infection with COVID-19 and other coronaviruses. Brain Behav Immun. 2020.

33. Wang $\mathrm{D}, \mathrm{Hu} \mathrm{B}, \mathrm{Hu} \mathrm{C}$, et al. Clinical characteristics of 138 hospitalized patients with 2019 novel Coronavirus-infected pneumonia in Wuhan, China. JAMA. 2020;323:1061-1069. doi:10.1001/jama.2020.1585

34. Mo P, Xing Y, Xiao Y, et al. Clinical characteristics of refractory COVID-19 pneumonia in Wuhan, China. Clin Infect Dis. 2020. doi:10.1093/cid/ciaa270

35. Netland J, Meyerholz DK, Moore S, Cassell M, Perlman S. Severe acute respiratory syndrome coronavirus infection causes neuronal death in the absence of encephalitis in mice transgenic for human ACE2. J Virol. 2008;82(15):7264-7275. doi:10.1128/ JVI.00737-08

36. Li K, Wohlford-Lenane C, Perlman S, et al. Middle east respiratory syndrome coronavirus causes multiple organ damage and lethal disease in mice transgenic for human dipeptidyl peptidase 4. J Infect Dis. 2016;213(5):712-722. doi:10.1093/infdis/jiv499
37. Li YC, Bai WZ, Hashikawa T. The neuroinvasive potential of SARS-CoV2 may play a role in the respiratory failure of COVID-19 patients. J Med Virol. 2020.

38. Li Z, Liu T, Yang N, et al. Neurological manifestations of patients with COVID-19: potential routes of SARS-CoV-2 neuroinvasion from the periphery to the brain. Front Med. 2020;14(5):533-541. doi:10.1007/s11684-020-0786-5

39. Panariello F, Cellini L, Speciani M, De Ronchi D, Atti AR. How does SARS-CoV-2 affect the central nervous system? A working hypothesis. Front Psychiatry. 2020;11:582345. doi:10.3389/ fpsyt.2020.582345

40. Mao L, Jin H, Wang M, et al. Neurologic manifestations of hospitalized patients with Coronavirus disease 2019 in Wuhan, China. JAMA Neurol. 2020;77:683.

41. Gautier JF, Ravussin Y. A new symptom of COVID-19: loss of taste and smell. Obesity (Silver Spring). 2020;28:848. doi:10.1002/oby.22809

42. Das G, Mukherjee N, Ghosh S. Neurological insights of COVID-19 pandemic. ACS Chem Neurosci. 2020;11:1206-1209. doi:10.1021/acschemneuro.0c00201

43. $\mathrm{Hu} \mathrm{X,} \mathrm{Xing} \mathrm{Y,} \mathrm{Jia} \mathrm{J,} \mathrm{et} \mathrm{al.} \mathrm{Factors} \mathrm{associated} \mathrm{with} \mathrm{negative}$ conversion of viral RNA in patients hospitalized with COVID-19. Sci Total Environ. 2020;728:138812. doi:10.1016/j. scitotenv.2020.138812

44. Turner R, Wevrett SR, Edmunds S, et al. Determination of the permeation and penetration of flurbiprofen into cadaveric human pharynx tissue. Clin Pharmacol. 2020;12:13-20. doi:10.2147/ CPAA.S234227

45. Essack S, Bell J, Burgoyne DS, Duerden M, Shephard A. Topical (local) antibiotics for respiratory infections with sore throat: an antibiotic stewardship perspective. J Clin Pharm Ther. 2019;44 (6):829-837. doi:10.1111/jcpt.13012

46. Hayward G, Thompson MJ, Perera R, Glasziou PP, Del Mar CB, Heneghan CJ. Corticosteroids as standalone or add-on treatment for sore throat. Cochrane Database Syst Rev. 2012;10:Cd008268. doi:10.1002/14651858.CD008268.pub2

47. de Looze F, Shephard A, Smith AB. Locally delivered flurbiprofen $8.75 \mathrm{mg}$ for treatment and prevention of sore throat: a narrative review of clinical studies. $J$ Pain Res. 2019;12:3477-3509. doi:10.2147/JPR.S221706

48. Weckmann G, Hauptmann-Voss A, Baumeister SE, Klotzer C, Chenot JF. Efficacy of AMC/DCBA lozenges for sore throat: a systematic review and meta-analysis. Int $J$ Clin Pract. 2017;71(10):e13002. doi:10.1111/ijcp.13002

49. Ng GJ, Tan S, Vu AN, Del Mar CB, van Driel ML, Antibiotics for preventing recurrent sore throat. Cochrane Database Syst Rev. 2015;7:Cd008911. doi:10.1002/14651858. CD008911.pub2

50. Oxford JS, Leuwer M. Acute sore throat revisited: clinical and experimental evidence for the efficacy of over-the-counter AMC/ DCBA throat lozenges. Int J Clin Pract. 2011;65(5):524-530. doi:10.1111/j.1742-1241.2011.02644.x

51. Garg S, Kim L, Whitaker M, et al. Hospitalization rates and characteristics of patients hospitalized with laboratory-confirmed Coronavirus disease 2019 - COVID-NET, 14 States, March 1-30, 2020. MMWR Morb Mortal Wkly Rep. 2020;69(15):458-464. doi:10.15585/mmwr.mm6915e3

52. Pung R, Chiew CJ, Young BE, et al. Investigation of three clusters of COVID-19 in Singapore: implications for surveillance and response measures. Lancet. 2020;395(10229):1039-1046. doi:10.1016/S0140-6736(20)30528-6

53. Xia S, Liu M, Wang C, et al. Inhibition of SARS-CoV-2 (previously $2019-\mathrm{nCoV}$ ) infection by a highly potent pan-coronavirus fusion inhibitor targeting its spike protein that harbors a high capacity to mediate membrane fusion. Cell Res. 2020;30 (4):343-355. doi:10.1038/s41422-020-0305-x 
54. Grant WB, Lahore H, McDonnell SL, et al. Evidence that vitamin D supplementation could reduce risk of influenza and COVID-19 infections and deaths. Nutrients. 2020;12(4).

55. Krajewska J, Krajewski W, Zub K, Zatonski T. COVID-19 in otolaryngologist practice: a review of current knowledge. Eur Arch Otorhinolaryngol. 2020;277:1885-1897. doi:10.1007/ s00405-020-05968-y

56. Yan CH, Faraji F, Prajapati DP, Boone CE, DeConde AS. Association of chemosensory dysfunction and Covid-19 in patients presenting with influenza-like symptoms. Int Forum Allergy Rhinol. 2020;10:806-813. doi:10.1002/alr.22579

57. Gorse GJ, Donovan MM, Patel GB, Balasubramanian S, Lusk RH. Coronavirus and other respiratory illnesses comparing older with young adults. Am J Med. 2015;128(11):1251.e12111220. doi:10.1016/j.amjmed.2015.05.034

58. Lechien JR, Chiesa-Estomba CM, Place S, et al. Clinical and epidemiological characteristics of 1420 European patients with mild-to-moderate Coronavirus disease 2019. J Intern Med. 2020;288:335-344. doi:10.1111/joim.13089

59. Chan EK, Kornberg AJ, Ryan MM. A diagnostic approach to recurrent myalgia and rhabdomyolysis in children. Arch Dis Child. 2015;100(8):793-797. doi:10.1136/archdischild-2014307663

60. Kyriakides T, Angelini C, Schaefer J, et al. EFNS review on the role of muscle biopsy in the investigation of myalgia. Eur J Neurol. 2013;20(7):997-1005. doi:10.1111/ene.12174

61. Queme LF, Ross JL, Jankowski MP. Peripheral mechanisms of ischemic myalgia. Front Cell Neurosci. 2017;11:419. doi:10.3389/fncel.2017.00419

62. Irwin ML, Cartmel B, Gross CP, et al. Randomized exercise trial of aromatase inhibitor-induced arthralgia in breast cancer survivors. J Clin Oncol. 2015;33(10):1104-1111. doi:10.1200/ JCO.2014.57.1547

63. Castel LD, Hartmann KE, Mayer IA, et al. Time course of arthralgia among women initiating aromatase inhibitor therapy and a postmenopausal comparison group in a prospective cohort. Cancer. 2013;119(13):2375-2382. doi:10.1002/ cncr. 28016

64. Tian Z, Wang DS, Wang XS, et al. Analgesic effects of NB001 on mouse models of arthralgia. Mol Brain. 2015;8(1):60 doi:10.1186/s13041-015-0151-9

65. Luque-Suarez A, Martinez-Calderon J, Falla D. Role of kinesiophobia on pain, disability and quality of life in people suffering from chronic musculoskeletal pain: a systematic review. $\mathrm{Br}$ J Sports Med. 2019;53(9):554-559. doi:10.1136/bjsports-2017098673

66. Li X, Zeng W, Li X, et al. CT imaging changes of corona virus disease 2019(COVID-19): a multi-center study in Southwest China. J Transl Med. 2020;18(1):154. doi:10.1186/s12967-02002324-w

67. Manjavachi MN, Motta EM, Marotta DM, Leite DF, Calixto JB Mechanisms involved in IL-6-induced muscular mechanical hyperalgesia in mice. Pain. 2010;151(2):345-355. doi:10.1016/j. pain.2010.07.018

68. Drożdżal S, Rosik J, Lechowicz K, et al. COVID-19: pain management in patients with SARS-CoV-2 infection-molecular mechanisms, challenges, and perspectives. Brain Sci. 2020;10 (7):465. doi:10.3390/brainsci10070465

69. Khodabukus A, Kaza A, Wang J, et al. Tissue-engineered human myobundle system as a platform for evaluation of skeletal muscle injury biomarkers. Toxicol Sci. 2020;176:124-136. doi:10.1093/ toxsci/kfaa049

70. Li MY, Li L, Zhang Y, Wang XS. Expression of the SARS-CoV-2 cell receptor gene ACE2 in a wide variety of human tissues. Infect Dis Poverty. 2020;9(1):45. doi:10.1186/s40249-020-00662-x
71. Ding Y, He L, Zhang Q, et al. Organ distribution of severe acute respiratory syndrome (SARS) associated coronavirus (SARS-CoV) in SARS patients: implications for pathogenesis and virus transmission pathways. $J$ Pathol. 2004;203 (2):622-630. doi:10.1002/path.1560

72. Tostmann A, Bradley J, Bousema T, et al. Strong associations and moderate predictive value of early symptoms for SARS-CoV-2 test positivity among healthcare workers, the Netherlands, March 2020. Euro Surveill. 2020;25(16). doi:10.2807/1560-7917. ES.2020.25.16.2000508.

73. Jin M, Tong Q. Rhabdomyolysis as potential late complication associated with COVID-19. Emerg Infect Dis. 2020;26 (7):1618-1620. doi:10.3201/eid2607.200445

74. Chen LL, Hsu CW, Tian YC, Fang JT. Rhabdomyolysis associated with acute renal failure in patients with severe acute respiratory syndrome. Int J Clin Pract. 2005;59(10):1162-1166. doi:10.1111/j.1368-5031.2005.00540.x

75. Nance JR, Mammen AL. Diagnostic evaluation of rhabdomyolysis. Muscle Nerve. 2015;51(6):793-810. doi:10.1002/mus.24606

76. Joob B, Wiwanitkit V. Arthralgia as an initial presentation of COVID-19: observation. Rheumatol Int. 2020;40(5):823. doi:10.1007/s00296-020-04561-0

77. Ruigomez A, Rodriguez LA, Wallander MA, Johansson S, Jones R. Chest pain in general practice: incidence, comorbidity and mortality. Fam Pract. 2006;23(2):167-174. doi:10.1093/fam$\mathrm{pra} / \mathrm{cmi} 124$

78. Shi S, Qin M, Shen B, et al. Association of cardiac injury with mortality in hospitalized patients with COVID-19 in Wuhan, China. JAMA Cardiol. 2020;5:802.

79. COVID-19 National Incident Room Surveillance Team. COVID19, Australia: epidemiology report 9 (reporting week to 23:59 AEDT 29 March 2020). Commun Dis Intell (2018). 2020;44.

80. Wang R, Pan M, Zhang X, et al. Epidemiological and clinical features of 125 hospitalized patients with COVID-19 in Fuyang, Anhui, China. Int J Infect Dis. 2020.

81. Oudit GY, Kassiri Z, Jiang C, et al. SARS-coronavirus modulation of myocardial ACE2 expression and inflammation in patients with SARS. Eur J Clin Invest. 2009;39(7):618-625. doi:10.1111/ j.1365-2362.2009.02153.x

82. Reamy BV, Williams PM, Odom MR. Pleuritic chest pain: sorting through the differential diagnosis. Am Fam Physician. 2017;96 (5):306-312.

83. Zheng YY, Ma YT, Zhang JY, Xie X. COVID-19 and the cardiovascular system. Nat Rev Cardiol. 2020;17(5):259-260. doi:10.1038/s41569-020-0360-5

84. Leung C. Risk factors for predicting mortality in elderly patients with COVID-19: a review of clinical data in China. Mech Ageing Dev. 2020;188:111255. doi:10.1016/j.mad.2020.111255

85. Wu Q, Zhou L, Sun X, et al. Altered lipid metabolism in recovered SARS patients twelve years after infection. Sci Rep. 2017;7 (1):9110. doi:10.1038/s41598-017-09536-z

86. Viniol A, Keunecke C, Biroga T, et al. Studies of the symptom abdominal pain - a systematic review and meta-analysis. Fam Pract. 2014;31(5):517-529. doi:10.1093/fampra/cmu036

87. Bharucha AE, Chakraborty S, Sletten CD. Common functional gastroenterological disorders associated with abdominal pain. Mayo Clin Proc. 2016;91(8):1118-1132. doi:10.1016/j. mayocp.2016.06.003

88. Walter SA, Jones MP, Talley NJ, et al. Abdominal pain is associated with anxiety and depression scores in a sample of the general adult population with no signs of organic gastrointestinal disease. Neurogastroenterol Motil. 2013;25(9):741-e576. doi:10.1111/nmo.12155

89. Zhang JJ, Dong X, Cao YY, et al. Clinical characteristics of 140 patients infected with SARS-CoV-2 in Wuhan, China. Allergy. 2020;75:1730-1741. doi:10.1111/all.14238 
90. Zhou S, Wang Y, Zhu T, Xia L. CT features of Coronavirus disease 2019 (COVID-19) pneumonia in 62 patients in Wuhan, China. AJR Am J Roentgenol. 2020;1-8.

91. Luo S, Zhang X, Xu H. Don't overlook digestive symptoms in patients with 2019 novel Coronavirus disease (COVID-19). Clin Gastroenterol Hepatol. 2020;18:1636-1637. doi:10.1016/j. cgh.2020.03.043

92. Harmer D, Gilbert M, Borman R, Clark KL. Quantitative mRNA expression profiling of ACE 2, a novel homologue of angiotensin converting enzyme. FEBS Lett. 2002;532(1-2):107-110. doi:10.1016/S0014-5793(02)03640-2

93. Xiao F, Tang M, Zheng X, Liu Y, Li X, Shan H. Evidence for gastrointestinal infection of SARS-CoV-2. Gastroenterology. 2020;158(6):1831-1833.e1833. doi:10.1053/j.gastro.2020.02.055

94. Moustaki M, Zeis PM, Katsikari M, et al. Mesenteric lymphadenopathy as a cause of abdominal pain in children with lobar or segmental pneumonia. Pediatr Pulmonol. 2003;35(4):269-273. doi:10.1002/ppul.10254

95. Tian Y, Rong L, Nian W, He Y. Review article: gastrointestinal features in COVID-19 and the possibility of faecal transmission. Aliment Pharmacol Ther. 2020;51(9):843-851. doi:10.1111/ apt.15731

96. Saeed U, Sellevoll HB, Young VS, Sandbaek G, Glomsaker T, Mala T. Covid-19 may present with acute abdominal pain. $\mathrm{Br}$ J Surg. 2020;107:e186-e187. doi:10.1002/bjs.11674

97. Sun T, Guan J. Novel coronavirus and the central nervous system. Eur J Neurol. 2020;27. doi:10.1111/ene.14227

98. Tian S, Hu N, Lou J, et al. Characteristics of COVID-19 infection in Beijing. $J$ Infect. 2020;80(4):401-406. doi:10.1016/j. jinf.2020.02.018

99. Xu YH, Dong JH, An WM, et al. Clinical and computed tomographic imaging features of novel coronavirus pneumonia caused by SARS-CoV-2. J Infect. 2020;80(4):394-400. doi:10.1016/j. jinf.2020.02.017

100. Yang W, Cao Q, Qin L, et al. Clinical characteristics and imaging manifestations of the 2019 novel coronavirus disease (COVID-19): a multi-center study in Wenzhou city, Zhejiang, China. $J$ Infect. 2020;80(4):388-393. doi:10.1016/j. jinf.2020.02.016

101. Guan W-J, Ni Z-Y, Hu Y, et al. Clinical characteristics of Coronavirus disease 2019 in China. $N$ Engl J Med. 2020;382 (18):1708-1720.

102. Wu J, Liu J, Zhao X, et al. Clinical characteristics of imported cases of Coronavirus disease 2019 (COVID-19) in Jiangsu Province: a multicenter descriptive study. Clin Infect Dis. 2020;71(15):706-712. doi:10.1093/cid/ciaa199

103. Huang Y, Tu M, Wang S, et al. Clinical characteristics of laboratory confirmed positive cases of SARS-CoV-2 infection in Wuhan, China: a retrospective single center analysis. Travel Med Infect Dis. 2020;36:101606. doi:10.1016/j. tmaid.2020.101606

104. Liu K, Fang YY, Deng Y, et al. Clinical characteristics of novel coronavirus cases in tertiary hospitals in Hubei Province. Chin Med $\quad J \quad$ (Engl). 2020;133(9):1025-1031. doi:10.1097/ CM9.0000000000000744

105. Zhou F, Yu T, Du R, et al. Clinical course and risk factors for mortality of adult inpatients with COVID-19 in Wuhan, China: a retrospective cohort study. Lancet. 2020;395 (10229):1054-1062. doi:10.1016/S0140-6736(20)30566-3

106. Xu T, Chen $\mathrm{C}$, Zhu Z, et al. Clinical features and dynamics of viral load in imported and non-imported patients with COVID-19. Int J Infect Dis. 2020;94:68-71. doi:10.1016/j.ijid.2020.03.022

107. Wan S, Xiang Y, Fang W, et al. Clinical features and treatment of COVID-19 patients in northeast Chongqing. J Med Virol. 2020;92 (7):797-806. doi:10.1002/jmv.25783
108. Chen J, Qi T, Liu L, et al. Clinical progression of patients with COVID-19 in Shanghai, China. J Infect. 2020;80(5):e1-e6. doi:10.1016/j.jinf.2020.03.004

109. COVID-19 National Incident Room Surveillance Team. COVID19, Australia: epidemiology report 7 (reporting week ending 19:00 AEDT 14 March 2020). Commun Dis Intell (2018). 2020;44.

110. Zhou S, Wang Y, Zhu T, Xia L. CT features of Coronavirus disease 2019 (COVID-19) pneumonia in 62 patients in Wuhan, China. AJR Am J Roentgenol. 2020;214(6):1287-1294. doi:10.2214/AJR.20.22975

111. Han R, Huang L, Jiang H, Dong J, Peng H, Zhang D. Early clinical and CT manifestations of Coronavirus disease 2019 (COVID-19) pneumonia. AJR Am J Roentgenol. 2020;215 (2):338-343. doi:10.2214/AJR.20.22961

112. Song F, Shi N, Shan F, et al. Emerging 2019 novel Coronavirus (2019-nCoV) pneumonia. Radiology. 2020;295(1):210-217. doi:10.1148/radiol.2020200274

113. Qian GQ, Yang NB, Ding F, et al. Epidemiologic and clinical characteristics of 91 hospitalized patients with COVID-19 in Zhejiang, China: a retrospective, multi-centre case series. QJM. 2020;113(7):474-481. doi:10.1093/qjmed/hcaa089

114. Spiteri G, Fielding J, Diercke M, et al. First cases of coronavirus disease 2019 (COVID-19) in the WHO European Region, 24 January to 21 February 2020. Euro Surveill. 2020;25(9). doi:10.2807/1560-7917.ES.2020.25.9.2000178.

115. $\mathrm{Xu} \mathrm{X,} \mathrm{Yu} \mathrm{C,} \mathrm{Qu} \mathrm{J,} \mathrm{et} \mathrm{al.} \mathrm{Imaging} \mathrm{and} \mathrm{clinical} \mathrm{features} \mathrm{of} \mathrm{patients} \mathrm{with}$ 2019 novel coronavirus SARS-CoV-2. Eur J Nucl Med Mol Imaging. 2020;47(5):1275-1280. doi:10.1007/s00259-020-04735-9

116. Zhu W, Xie K, Lu H, Xu L, Zhou S, Fang S. Initial clinical features of suspected coronavirus disease 2019 in two emergency departments outside of Hubei, China. J Med Virol. 2020;92 (9):1525-1532. doi:10.1002/jmv.25763

117. Shi H, Han X, Jiang N, et al. Radiological findings from 81 patients with COVID-19 pneumonia in Wuhan, China: a descriptive study. Lancet Infect Dis. 2020;20(4):425-434. doi:10.1016/S1473-3099(20)30086-4

118. Zhao W, Zhong Z, Xie X, Yu Q, Liu J. Relation between chest CT findings and clinical conditions of Coronavirus disease (COVID-19) pneumonia: a multicenter study. AJR Am J Roentgenol. 2020;214 (5):1072-1077. doi:10.2214/AJR.20.22976

119. Wu C, Chen X, Cai Y, et al. Risk factors associated with acute respiratory distress syndrome and death in patients with Coronavirus disease 2019 pneumonia in Wuhan, China. JAMA Intern Med. 2020;180(7):934-943. doi:10.1001/jamainternmed.2020.0994

120. Wang Y, Dong C, Hu Y, et al. Temporal changes of CT findings in 90 patients with COVID-19 pneumonia: a longitudinal study. Radiology. 2020;296(2):E55-e64. doi:10.1148/radiol.2020200843

121. Mao L, Jin H, Wang M, et al. Neurologic manifestations of hospitalized patients with Coronavirus disease 2019 in Wuhan, China. JAMA Neurol. 2020;77(6):683-690.

122. Shi S, Qin M, Shen B, et al. Association of cardiac injury with mortality in hospitalized patients with COVID-19 in Wuhan, China. JAMA Cardiol. 2020;5(7):802-810.

123. on COVID NC. Daily situation report on Coronavirus disease (COVID-19) in Iran; March 13, 2020. Arch Acad Emerg Med. 2020;8(1):e23.

124. Wang K, Kang S, Tian R, Zhang X, Zhang X, Wang Y. Imaging manifestations and diagnostic value of chest $\mathrm{CT}$ of coronavirus disease 2019 (COVID-19) in the Xiaogan area. Clin Radiol. 2020;75(5):341-347. doi:10.1016/j.crad.2020.03.004

125. Cao J, Tu WJ, Cheng W, et al. Clinical features and short-term outcomes of 102 patients with Coronavirus disease 2019 in Wuhan, China. Clin Infect Dis. 2020;71(15):748-755. doi:10.1093/cid/ciaa243 
126. Zhang R, Ouyang $\mathrm{H}, \mathrm{Fu} \mathrm{L}$, et al. CT features of SARS-CoV-2 pneumonia according to clinical presentation: a retrospective analysis of 120 consecutive patients from Wuhan city. Eur Radiol. 2020;30(8):4417-4426. doi:10.1007/s00330-020-06854-1

127. Barrasa H, Rello J, Tejada S, et al. SARS-CoV-2 in Spanish INTENSIVE CARE UNITS: early experience with 15-day survival in Vitoria. Critical Care Pain Med. 2020;39(5):553-561. doi:10.1016/j.accpm.2020.04.001

128. Tang $\mathrm{X}$, Du RH, Wang R, et al. Comparison of hospitalized patients with ARDS caused by COVID-19 and H1N1. Chest. 2020;158(1):195-205. doi:10.1016/j.chest.2020.03.032

129. Sun Y, Koh V, Marimuthu K, et al. Epidemiological and clinical predictors of COVID-19. Clin Infect Dis. 2020;71(15):786-792. doi:10.1093/cid/ciaa322

130. Chen Z, Fan H, Cai J, et al. High-resolution computed tomography manifestations of COVID-19 infections in patients of different ages. Eur $J$ Radiol. 2020;126:108972. doi:10.1016/j. ejrad.2020.108972

131. Chen Y, Chen L, Deng Q, et al. The presence of SARS-CoV-2 RNA in the feces of COVID-19 patients. J Med Virol. 2020;92 (7):833-840. doi:10.1002/jmv.25825

132. Wang $\mathrm{X}$, Fang J, Zhu Y, et al. Clinical characteristics of non-critically ill patients with novel coronavirus infection (COVID-19) in a Fangcang Hospital. Clin Microbiol Infect. 2020;26(8):1063-1068. doi:10.1016/j.cmi.2020.03.032

133. Shao F, Xu S, Ma X, et al. In-hospital cardiac arrest outcomes among patients with COVID-19 pneumonia in Wuhan, China. Resuscitation. 2020;151:18-23. doi:10.1016/j.resuscitation.2020.04.005
134. Wang R, Pan M, Zhang X, et al. Epidemiological and clinical features of 125 hospitalized patients with COVID-19 in Fuyang, Anhui, China. Int J Infect Dis. 2020;95:421-428. doi:10.1016/j. ijid.2020.03.070

135. Du RH, Liu LM, Yin W, et al. Hospitalization and critical care of 109 decedents with COVID-19 pneumonia in Wuhan, China. Ann Am Thorac Soc. 2020;17(7):839-846. doi:10.1513/AnnalsATS.202003$225 \mathrm{OC}$

136. Jia J, Hu X, Yang F, et al. Epidemiological characteristics on the clustering nature of COVID-19 in Qingdao City, 2020 a descriptive analysis. Disaster Med Public Health Prep. 2020;14(5):643-647. doi:10.1017/dmp.2020.59

137. Feng Y, Ling Y, Bai T, et al. COVID-19 with different severities: a multicenter study of clinical features. Am J Respir Crit Care Med. 2020;201(11):1380-1388. doi:10.1164/rccm.202002-0445OC

138. Zheng F, Tang W, Li H, Huang YX, Xie YL, Zhou ZG. Clinical characteristics of 161 cases of corona virus disease 2019 (COVID-19) in Changsha. Eur Rev Med Pharmacol Sci. 2020;24(6):3404-3410. doi:10.26355/eurrev_202003_20711

139. Du Y, Tu L, Zhu P, et al. Clinical features of 85 fatal cases of COVID-19 from Wuhan. A retrospective observational study. Am J Respir Crit Care Med. 2020;201(11):1372-1379. doi:10.1164/ rccm.202003-0543OC
Journal of Pain Research

\section{Publish your work in this journal}

The Journal of Pain Research is an international, peer reviewed, open access, online journal that welcomes laboratory and clinical findings in the fields of pain research and the prevention and management of pain. Original research, reviews, symposium reports, hypothesis formation and commentaries are all considered for publication. The manuscript
Dovepress

management system is completely online and includes a very quick and fair peer-review system, which is all easy to use. Visit http:// www.dovepress.com/testimonials.php to read real quotes from published authors. 